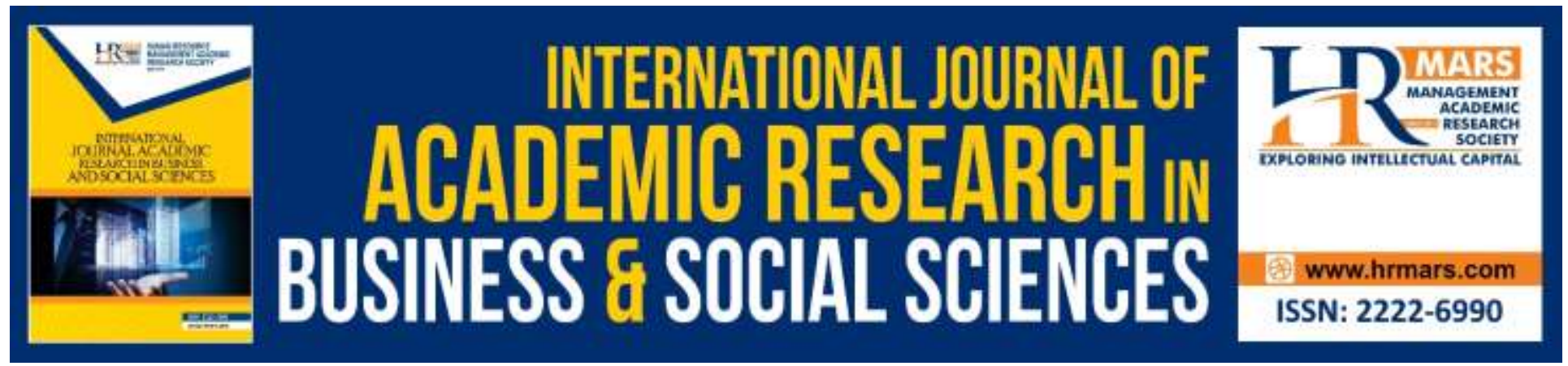

\title{
Role of Customer's Orientation and Professional Skill of a Service Provider in the Telecom Sector of Pakistan
}

\author{
Muhammad Naeem Sharif, Hassan Raza, Muhammad Faizan, Naveed UI \\ Hassan
}

To Link this Article: http://dx.doi.org/10.6007/IJARBSS/v9-i10/6815

DOI: 10.6007/IJARBSS/v9-i10/6815

Received: 19 August 2019, Revised: 02 September 2019, Accepted: 22 September 2019

Published Online: 29 Oct 2019

In-Text Citation: (Sharif et al., 2019)

To Cite this Article: Sharif, M. N., Raza, H., Faizan, M., \& Hassan, N. U. (2019). Role of Customer's Orientation and Professional Skill of a Service Provider in the Telecom Sector of Pakistan. International Journal of Academic Research in Business and Social Sciences, 9(10), 385-393.

Copyright: (c) 2019 The Author(s)

Published by Human Resource Management Academic Research Society (www.hrmars.com)

This article is published under the Creative Commons Attribution (CC BY 4.0) license. Anyone may reproduce, distribute, translate and create derivative works of this article (for both commercial and non-commercial purposes), subject to full attribution to the original publication and authors. The full terms of this license may be seen

at: http://creativecommons.org/licences/by/4.0/legalcode

Vol. 9, No. 10, 2019, Pg. 385 - 393

http://hrmars.com/index.php/pages/detail/IJARBSS

JOURNAL HOMEPAGE

Full Terms \& Conditions of access and use can be found at http://hrmars.com/index.php/pages/detail/publication-ethics 


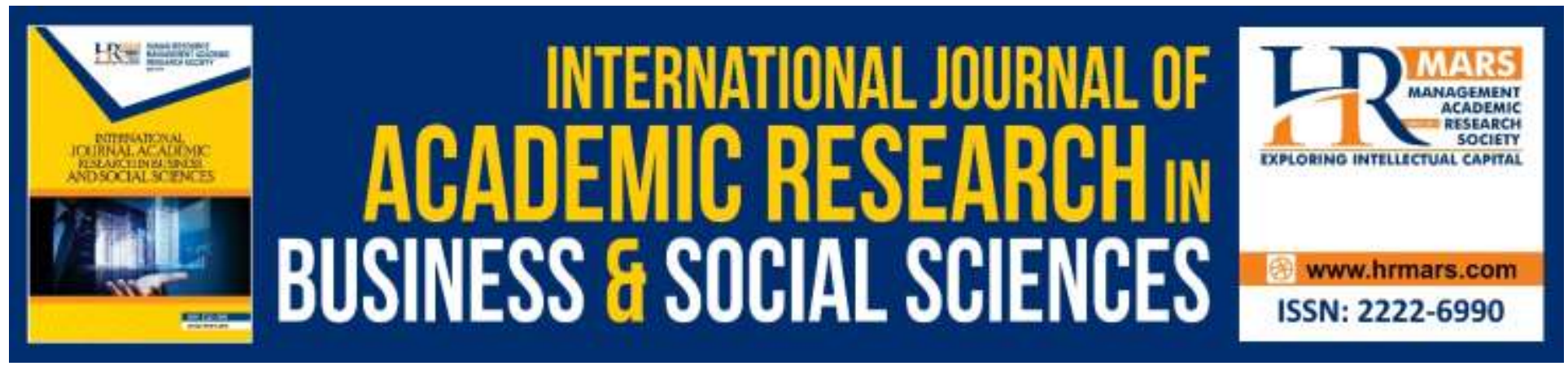

\title{
Role of Customer's Orientation and Professional Skill of a Service Provider in the Telecom Sector of Pakistan
}

\author{
Muhammad Naeem Sharif \\ National College of Business Administration and Economics, Lahore \\ Email: naeemsharif.umt@gmail.com \\ Hassan Raza \\ PUCIT, University of the Punjab Lahore \\ Email: hraza5905@gmail.com \\ Muhammad Faizan \\ COMSATS institute of technology, Lahore \\ Email: Faizanazmat82@gmail.com \\ Naveed UI Hassan \\ National College of Business Administration \& Economics Lahore
}

\begin{abstract}
Telecom sector of Pakistan has very important role in economy of the country. Innovation is crucially important for telecom industry, which can bring lot of changes in the service sector and improve the service in the telecom industry. Some of the special issues which are arise in the telecom industry that was differentiation between product and process or between network and services innovation. The current study is collected the 40 responses from 6 telecom companies of Pakistan. The current found that positive relationship between customer orientation, and service innovation in telecom industry of Pakistan. On the other side, the study found the insignificant relationship between professional skills and service innovation. The current study suggested that the telecommunication organizations should focus and improved the professional skills, which can improve their growth.
\end{abstract}




\section{Introduction}

Pakistan telecom market is one of the world's fastest developing industries. Today the telecom trends are changes rapidly which has positive effect overall economic growth of the country (Hussain \& Aslam, 2019). Telecommunications industry is an most competitive and important industry of Pakistan. The Telecommunication sector in Pakistan has been improving very fast and comparing its telecom services with global advancements. Six major national and multinational operators are providing GSM/Cellular services in all over the Pakistan. These operators are named as Pakistan Mobile Company Limited (36.7 million subscribers at May, 13), China Mobile Pakistan (20.2 million Subscribers at May, 2013), Telenor Pakistan Limited (23.7 million Subscribers at May, 2013), Warid Telecom Limited (12.5 million Subscribers at May, 2013), Ufone (23.9 million Subscribers at May, 2013) and PTCL. Basic telephony, IP services, wireless and mobile markets and technologies, broadband markets and technologies are the services provided by Pakistan Telecommunication Company limited. Furthermore, the telecom industry contributed around USD 37 Million (Ibrahim, Shahid, \& Ahmed, 2014).

Furthermore, the government of Pakistan issues the license of $3 G$ and $4 G$ network that can enhance the telecommunication trends in the Pakistan. 3G technology is the new innovation which allow a broadband wireless access to the internet and which may provide individuals with location, time and context-based services and enable mobile business functions (May, 2001). Today due to technological advancement organization move upward because customer want change in the telecom sector, so all telecom companies are adapting a new service. The new service cannot achieve without customer orientation and skilled professionals. These skills are very important to achieve the customer satisfaction.

Therefore, the main objective of the study is to investigate the role of customer orientation and professional skills in service innovation of telecom industry in Pakistan.

\section{Literature Review}

\section{Telecom trends in Pakistan}

Pakistan telecom industry is one of the world's fastest growing market. The telecom trends are changes rapidly day by day, which also has positive effect overall economic growth of the country (Manyika \& Roxburgh, 2011). Telecom trends are changes rapidly in last two decades. Public telecommunication companies are completely or incompletely privatized in most of the countries, such as the Pakistan Telecommunication Company Limited (PTCL) converters in privatization. The PTCL plans to increase number of internet connections, which shift from 400 to 800 users. The company makes decision to advance different subsidiary telecommunication accommodate to increase the quality of service for consumers (Ansari \& Khan, 2009). IN past, telecommunication sector of Pakistan was lagging behind than Thailand due to political intervenes ad these days telecommunication industry of Pakistan improved significantly and left the behind to Thailand.

In the Pakistan telecom sector have extraordinary growth in the last sex year. In the early days only two operators are worked name as Instaphone and Warid telecom and in these days six operators are working in Pakistan (Bhatti, 2008). Pakistan cell phone telecom companies have played an important role in encouraging the development in the telecommunication sector. 
Telenor and Zong is fastest network in Pakistan. These phone operators improved their performance in very short period of time. The main reason of Pakistan telecom market is introduce the new market innovative strategies such as prepaid international roaming, international mms and reduce international call rates and mobile tv etc (Gao \& Rafiq, 2009).

\section{Innovation}

Innovation play an important role in the performance of service sector, such as telecom sector (YuSheng \& Ibrahim, 2019). The innovation capability is achieving the firms competitive advantages (Salunke, Weerawardena, \& McColl-Kennedy, 2019). According to Kim and Mauborgne (1999) that innovation is a necessary component for any company higher performance. According to Schumpeter and McCraw (2007) that innovation was started form the first half of the 20th century and differentiation has been made in economic theory between invention, innovation and diffusion. There are many types of Innovations, such as product innovation, process innovation and marketing innovation. However, more discussed in literature are product and process innovation. The process innovation can be visible to all user of the organization in the shape of new product.

Innovation in Telecom Sector is very important, As of now, telecommunication sector is significantly contributing in countries' economies (Patil, Singh, Chavan, Gadkari, \& Chaturvedi, 2014). There are different types of network under the mobile and fixed network in the telecom industry. Policy makers check it out that which policy and innovation give return/benefits which type of network technology can be deployed at a cheaper costing the telecom industry. In the telecom industry innovation and network (Williams, 2011). $3 \mathrm{G}$ technology is the new innovation which allow a broadband wireless access to the internet and which may provide individuals with location, time and context based services and enable mobile business functions (May, 2001). $3 G$ technology is the advance technology which provides a customer a lot of service to connect with each other and also enables the mobile that all things which comes through innovation through new ideas which is come in the telecom industry. The infrastructure that favors adoption can over time become an inertia that constrains innovation so the infrastructure in any telecommunication company adopts an innovation through which they made the infrastructure good (Ibrahim et al., 2014).

There are many factors influencing the service innovation of telecommunication sector, however, some of customer orientation and professional skills are most considerable factors. The main purpose of this study is also to investigate the relationship between, customer orientation, professional skills and service innovation in telecommunication sector of Pakistan.

\section{Customer Orientation}

The customer orientation means that developing a quality of product value and respectfully handle the customer complaints regarding service delivery. Basically, the customer loyalty in the telecom sector is divided into three broader categories such that behavior approach, attitude approach, integrated approach (Bresnahan \& Trajtenberg, 1995). The integrated approach is the combination of behavior and attitude approach which takes into account in this research customer orientation how effected through loyalty. Earlier studies stated that the factors 
affecting customer loyalty usually set the focus on customer satisfaction and orientation (Lee \& Cunningham, 2001). Customers experiencing a high level of satisfaction are likely to remain with their existing providers and maintain their contribution. However, according to past researches, customer satisfaction positively influencing customer loyalty (Jones, Mothersbaugh, \& Beatty, 2002).

However, according to Jaworski and Kohli (1996) said that the consequences of market orientation are classified into four main categories such as organizational performance, customer consequences, innovation consequences, and employee consequences. The main attention is about innovation, or service innovation. A successful business must be innovative and different to others in its nature for the following reasons: (1) to learn more and convince customers needs and wants, (2) to held successfully the process of developing new products or services that address those needs and wants and (3) to help in administer internal activities and procedure that increase product development process and customers' needs understanding (Narver, Slater, \& MacLachlan, 2004).

According to past literature that the customer satisfaction is the important in telecom industry and they refers that customer satisfaction is the evaluation their business (Edvardsson, Johnson, Gustafsson, \& Strandvik, 2000). Another researcher said that satisfaction the evaluation of product which the use or purchase and service which the customer want (Olsen \& Johnson, 2003).

\section{Professional Skill}

Professional skills are important for the success of telecom sector. The quantity and excellence expertise has been central matter particularly in high development stage which the telecom sector in many states gone through. In addition information and communication technology in these days widely incorporated the purpose of whole economy and societies the potential skills and knowledge are to be getting extremely (Pohjola, 2002).

In the laborious economy, the human resource is more important factor behind the achievement of the organizations. Now days the overall importance of the ICT has increase as it is these days extensively integrated all function of whole economy as like business and society in the current researches the new skills and knowledge are required for the ICT firm in which the some are educational degrees and other are often abilities of particular nature. Some of the important factor is like as attitude, individual communication skills are focus compulsory when firm are recruiting a new staff (Leppimaki, Tammi, \& Meristo, 2004).

\section{Framework}

The below table shows the relationship between variables, in which one is dependent variable like service innovation and two are independent variables like customer orientation and professional skills. 


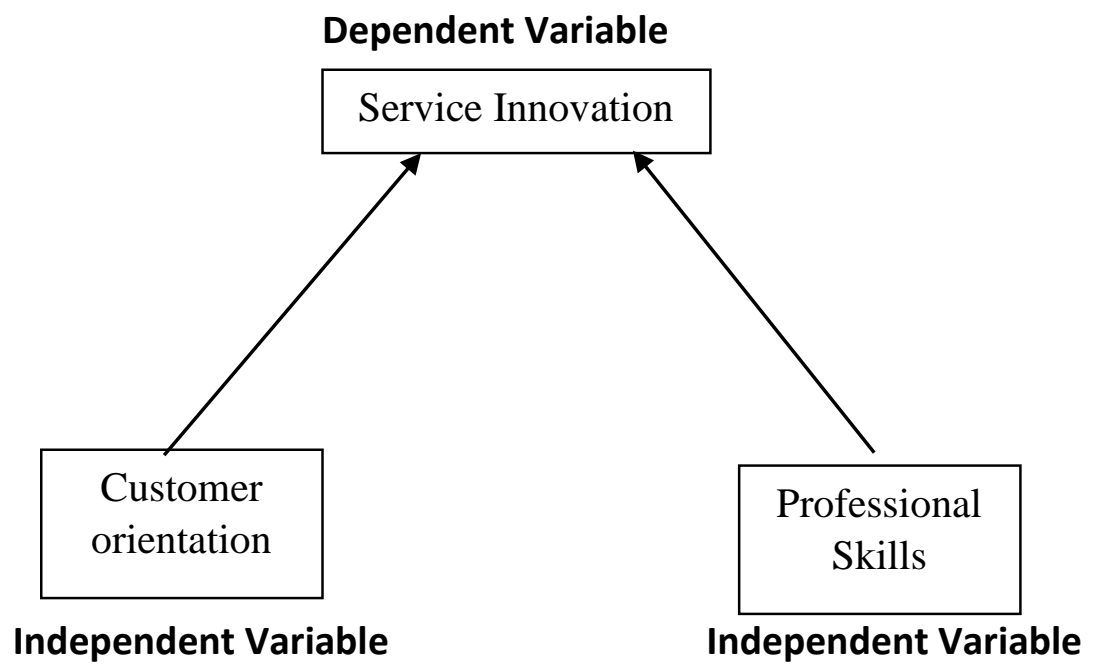

\section{Hypothesis}

H1: Customer orientation has strong impact on the service innovation.

H2: Professional skill has strong impact on service innovation.

\section{Methodology}

This study employed the quantitative techniques to investigate the role of customer's orientation and professional skill of a service provider on the service innovation in the telecom sector in Pakistan. In current research used the probability sampling techniques.

\section{Populations and the Sample}

We are conducted the research in the telecom sector of Pakistan and the total 6 telecom organization which are working in Pakistan were selected for sample collection. The organizations are Telenor, Mobilink, Ufone, Warid, Zong, PTCL.

\section{Sampling Design}

Total sample size is 40 and the researcher collected the data from two different cities such as Rawalpindi and Islamabad. Study selected the ten franchises from Islamabad region and ten are Rawalpindi region.

\section{Data Analysis}

A regression is statically tool that used to determine the relation between the dependent and independent variable. In this research the independent variable is customer orientation and professional skills and the dependent variable is service innovation. In the regression model result shows that the value of customer orientation is .001 and professional skills value is .117 at a significant level $\alpha=0.05$, if the value found more than 0.05 , it will consider the rejection of hypothesis. However, the current study found the value of hypothesis 1 less than 0.05 with 3.765 t-statistics, hence the hypothesis 1 is accepted. The values of second hypothesis recorder more 
than 0.05 with t-statistics 1.603 value, hence the hypothesis 2 is rejected. The result can be seen in table 1.

Table.1 Regression

Model Summary

\begin{tabular}{|c|c|c|c|c|c|c|c|c|c|}
\hline $\begin{array}{l}\text { Mod } \\
\text { el }\end{array}$ & $\mathrm{R}$ & $\begin{array}{l}\text { R } \\
\text { Square }\end{array}$ & $\begin{array}{l}\text { Adjuste } \\
\mathrm{d} \quad \mathrm{R} \\
\text { Square }\end{array}$ & $\begin{array}{l}\text { Std. Error } \\
\text { of the } \\
\text { Estimate }\end{array}$ & Change S & catistics & & & \\
\hline & $\begin{array}{l}\mathrm{R} \\
\text { Square } \\
\text { Change }\end{array}$ & $\begin{array}{l}\text { F } \\
\text { Change }\end{array}$ & df1 & $\mathrm{df} 2$ & $\begin{array}{ll}\text { Sig. } & F \\
\text { Change } & \end{array}$ & $\begin{array}{l}\mathrm{R} \\
\text { Square } \\
\text { Change }\end{array}$ & $\begin{array}{l}\mathrm{F} \\
\text { Change }\end{array}$ & df1 & df2 \\
\hline 1 & $.594(a)$ & .353 & .318 & .32251 & .353 & 10.107 & 2 & 37 & .000 \\
\hline
\end{tabular}

a Predictors: (Constant), professional skills, customer orientation

\begin{tabular}{|c|c|c|c|c|c|}
\hline \multicolumn{6}{|c|}{ Coefficients(a) } \\
\hline $\begin{array}{l}\text { Mod } \\
\text { el }\end{array}$ & \multicolumn{2}{|c|}{$\begin{array}{l}\text { Unstandardized } \\
\text { Coefficients }\end{array}$} & \multirow{2}{*}{$\begin{array}{l}\text { Standardize } \\
d \\
\text { Coefficients } \\
\text { Beta }\end{array}$} & \multirow{2}{*}{$\mathrm{t}$} & \multirow{2}{*}{$\begin{array}{l}\text { Sig. } \\
\text { Std. } \\
\text { Error }\end{array}$} \\
\hline & B & $\begin{array}{l}\text { Std. } \\
\text { Error }\end{array}$ & & & \\
\hline $\begin{array}{l}\text { (Constant) } \\
\text { customer } \\
\text { orientation } \\
\text { professional skills }\end{array}$ & $\begin{array}{l}-.490 \\
.834 \\
.288\end{array}$ & $\begin{array}{l}1.165 \\
.221 \\
.179\end{array}$ & $\begin{array}{l}.509 \\
.217\end{array}$ & $\begin{array}{r}-.420 \\
3.765 \\
1.603\end{array}$ & $\begin{array}{l}.677 \\
.001 \\
.117\end{array}$ \\
\hline
\end{tabular}

a Dependent Variable: service innovation

\section{Results and Discussion}

This study examined the relationship between customer orientation, professional skill and service innovation. Using a sample size is 40 and our respondents are professionals, this study surveyed in the telecom sector in Pakistan. To my knowledge, this is the first study to examine the Role of customer's orientation and professional skill of a service provider on the service innovation in the telecom sector in Pakistan. The current study found the positive and significant relationship between customer orientation and service innovation. Secondly this study found the insignificant result between professional skills and service innovation.

\section{Conclusion}

After the completion of all work, this study concluded that if the telecom companies give service innovation to customer then customer are more loyal towards the telecom sector but professional skills also necessary to increase the customer satisfaction. This research has conducted in Pakistani context, where the usage rate of mobile is high than other countries and researcher check the impact of customer orientation and professional skill of a service provider 
on the service innovation in the telecom sector in Pakistan. According to result shows that customer orientation has strong impact on service innovation in the telecom sector in Pakistan. Pakistan telecom sector growth has increase day by day in the early days only two telecom companies are working and now six telecom companies are working in Pakistan. Furthermore, professional skills need to be improved as well.

\section{Recommendation and Suggestion}

Telecom service operators should design and provide individual services to different groups based on gender and profession and according to their needs and wants.

Different characteristics of factors like customer orientation, Professional skills and Service Innovation are directly proportional to the use and service providers must increase their value to the best possible level like as make their services easily available with best quality and acceptable to their consumers.

As positive significant correlation has been seen among all research factors so Telecom service providers must consider the above discussed attributes, when they want to develop and offer a telecom service to their consumers.

\section{References}

Al-Manaseer, D. S., Al-Qudah, A. M. (2018). The Impact of Higher Education Output on Unemployment Rates in Jordan, International Journal of Academic Research in Accounting, Finance and Management Sciences 8 (2): 65-72.

Ansari, S., \& Khan, A. (2009). Telecommunication trends in Pakistan. Market Forces, 4(4).

Bhatti, B. (2008). State of telecom Industry in Pakistan. Available at:[Accessed 25 August 2008].

Bresnahan, T. F., \& Trajtenberg, M. (1995). General purpose technologies 'Engines of growth'? Journal of econometrics, 65(1), 83-108.

Edvardsson, B., Johnson, M. D., Gustafsson, A., \& Strandvik, T. (2000). The effects of satisfaction and loyalty on profits and growth: products versus services. Total quality management, 11(7), 917-927.

Gao, P., \& Rafiq, A. (2009). The transformation of the mobile telecommunications industry in Pakistan: A developing country perspective. Telecommunications policy, 33(5-6), 309-323.

Hussain, A., \& Aslam, A. (2019). The Influence of Deceptive Advertising and Consumer Loyalty in Telecommunication Industry. perception, 11(3).

Ibrahim, M., Shahid, M. K., \& Ahmed, S. F. (2014). The Impact of Telecom Services Characteristics on Consumer for Use in Pakistan. Advances in Economics and Business, 2(4), 172-179.

Jaworski, B. J., \& Kohli, A. K. (1996). Market orientation: review, refinement, and roadmap. Journal of Market-Focused Management, 1(2), 119-135.

Jones, M. A., Mothersbaugh, D. L., \& Beatty, S. E. (2002). Why customers stay: measuring the underlying dimensions of services switching costs and managing their differential strategic outcomes. Journal of business research, 55(6), 441-450.

Kim, W. C., \& Mauborgne, R. (1999). Strategy, value innovation, and the knowledge economy. MIT Sloan Management Review, 40(3), 41. 
Lee, M., \& Cunningham, L. F. (2001). A cost/benefit approach to understanding service loyalty. Journal of services Marketing, 15(2), 113-130.

Leppimaki, S., Tammi, M., \& Meristo, T. (2004). Professional skills in the ICT industry.

Manyika, J., \& Roxburgh, C. (2011). The great transformer: The impact of the Internet on economic growth and prosperity. McKinsey Global Institute, 1.

May, P. (2001). Mobile commerce: opportunities, applications, and technologies of wireless business (Vol. 3): Cambridge University Press.

Narver, J. C., Slater, S. F., \& MacLachlan, D. L. (2004). Responsive and proactive market orientation and new-product success. Journal of product innovation management, 21(5), 334-347.

Olsen, L. L., \& Johnson, M. D. (2003). Service equity, satisfaction, and loyalty: from transactionspecific to cumulative evaluations. Journal of Service Research, 5(3), 184-195.

Patil, S., Singh, V., Chavan, S., Gadkari, M., \& Chaturvedi, R. (2014). Knowledge and attitude regarding PCPNDT act among medical undergraduates: a study conducted in teaching institute Mumbai. Innovative Journal of Medical and Health Science, 4(2), 83-85.

Pohjola, M. (2002). The new economy: facts, impacts and policies. Information Economics and Policy, 14(2), 133-144.

Salunke, S., Weerawardena, J., \& McColl-Kennedy, J. R. (2019). The central role of knowledge integration capability in service innovation-based competitive strategy. Industrial marketing management, 76, 144-156.

Schumpeter, J., \& McCraw, T. K. (2007). Prophet of innovation: Belknap Press of Harvard University Press.

Williams, I. (2011). Telecom policy innovation: the role of free spectrum and telecommunication development in rural Ghana. Journal of technology management \& innovation, 6(3), 93105.

YuSheng, K., \& Ibrahim, M. (2019). Service innovation, service delivery and customer satisfaction and loyalty in the banking sector of Ghana. International Journal of Bank Marketing.

Yu, H., Izhar, T. A. T., Rafedzi, E. R. K., Husin, N., \& Mokhtar, W. N. H. W. (2018). Information Literacy Development through Resource-Based School Projects: Malaysian Students Experience. International Journal of Academic Research in Progressive Education and Development, 7(3), 211-225. 